\title{
BATASAN KEDEWASAAN DAN KECAKAPAN HUKUIM PEWASIAT IMENURUT KOMPILASI HUKUM ISLAM DAN KITAB UNDANG-UNDANG HUKUM PERDATA
}

\author{
Limitations of Adult and Discussion of Law Authority by Islamic Law and Perdata Law
}

\author{
I*Sanawiah \& ${ }^{2}$ Muhammad Zainul \\ ISenior Lecturer in Al Ahwal Al Syakhsiyah, Universitas Muhammadiyah Palangkaraya, RTA Milono St. Km. I,5, Palangka Raya, Indonesia \\ 2Student in Al Ahwal Al Syakhsiyah, Universitas Muhammadiyah Palangkaraya, RTA Milono St. Km. I,5, Palangka Raya, Indonesia \\ *e-mail : sanawiah@umpalangkaraya.ac.id
}

\begin{abstract}
ABSTRAK
Batasan kedewasaan dan kecakapan hukum pewasiat baik dalam masalah kedudukan batasan dan kecakapan pewasiat, Syarat pewasiat dan macam-macam batasan usia pewasiat menurut pandangan dan pendapat yang berbeda di kalangan Imam Mazhab dalam penetapan hukumnya. Tujuan penelitian ini yaitu untuk untuk mengakaji Batasan kedewasaan dan kecakapan hukum pewasiat menurut Kompilasi Hukum Islam dan Kitab Undang-Undang Perdata yang terdapat pada Kompilasi Hukum Islam Pasal I 94 ayat I dan Kitab Undang-Undang Hukum Perdata Pasal 897. Dalam Kompilasi Hukum Islam Pasal 194 ayat I tentang wasiat menyebutkan bahwa orang yang berwasiat harus mencapai umur $2 \mathrm{I}$ penuh dan berakal sehat ini merupakan syarat untuk mlekukan wasiat haruslah mencapai umur yang sudah di tentukan. Kitab Undang-Undang Hukum perdata menyebutkan dalam Pasal 897 menyebutkan bahwa orang yang berwasiat harus mencapai umur 18 tahun penuh, ini merupakan syarat penentuan untuk melakukan wasiat. Metode penelitian hukum Normatif menganalisis, perundangundangan yang terkait disajikan melalui metode deskriptif dan deduktif yang kemudian dianalisis untuk melihat letak persamaan dan perbedaan antara Kompilasi Hukum Islam dan Kitab Undang-Undang Hukum Perdata. Hasil penelitian ini adalah persamaan penentuan hukum Kompilasi Hukum Islam dan Kitab Undang-Undang Hukum Perdata yang menyatakan syarat orang yang berwasiat haruslah berakal sehat, adapun dalam penentuan kedewasaan yaitu 21 tahun berpatokan pada pasal $330 \mathrm{KUH}$ Perdata. Sedangkan untuk kecakapan hukum pada Pasal 426 KUH Perdata ber usia 18 tahun.
\end{abstract}

Kata kunci: Kedewasaan, Cakap Hukum, Pewasiat

\section{ABSTRACT}

Limitations of adulthood and lawfulness of the pewasiat both in terms of the position of limits and the ability of the pewasiat, the requirements of the pewasiat and the various limits of the age of the pewasiat according to different views and opinions among the Imam of the School in the determination of its law. The purpose of this study is to to assess the Limitations of adulthood and legal proficiency of pewasiat by Compilation of Islamic Law and Civil Code contained in the Compilation of Islamic Law Article 194 paragraph I and Book Civil Law Article 897. In Compilation of Islamic Law Article 194 paragraph I concerning the will specifies that the person who intends to reach the age of 21 full and sensible this is a requirement for mlekukan wills must reach the age that has been determined. The Civil Code states that in Article 897 it states that the person who intentions must reach the age of 18 full years, this is a condition of determination to perform the testament. Normative legal research methods analyze, related legislation presented through descriptive and deductive methods which are then analyzed to see the location of similarities and differences between the Compilation of Islamic Law and the Civil Code. The result of this research is the equation of Law Compilation of Compilation of Islamic Law and Civil Code which states the condition of the person having the will should be sensible, while in the determination of maturity 21 years based on article 330 Civil Code. As for the legal proof of Article 426 Civil Code aged 18 years.

Keywords: Maturity, Proficient Law, Testament

\section{PENDAHULUAN}

Wasiat merupakan salah satu perbuatan yang sudah lama dikenal sebelum Islam. Misalnya dalam masyarakat pada masa Arab jahiliah, banyak sekali wasiat yang diberikan kepada orang lain yang tidak mempunyai hubungan kekeluargaan dengan orang yang berwasiat, karena pada masa itu orang yang memberikan sebagian besar harta miliknya memperlambangkan orang yang sangat kaya raya dan mendapatkan pujian dari semua orang. Kemudian Islam datang membenarkan sudut pandang wasiat yang berdasarkan kepada asas hak dan keadilan, Islam mengharuskan orang-orang yang memiliki harta agar membuat wasiat untuk kedua orang tua dan para kerabat. Kata wasiat disebut dalam Al-Qur'an sebanyak 9 kali. Dalam bentuk kata kerja, wasiat disebut 14 kali, dan dalam bentuk kata benda jadian disebut 2 kali. Seluruhnya kata wasiat disebut sebanyak 25 kali.

Dalam penggunaannya, kata wasiat berarti: berpesan, menetapkan, memerintah (QS Al An'am, [6]:15I, 152, 153; Al-Nisa' [4]:131), mewajibkan (QS Al-'Ankabut [29]:8, Luqman [3I]:I4, Al-Syura [42]: 13, Al-Ahqaf [46]: 15), dan mensyariatkan (Al-Nisa' [4]:I I). Kata wasiat berasal dari washaya yang artinya orang yang berwasiat menghubungkan harta bendanya waktu hidup dengan sesudah mati. Orang 
yang berwasiat menyambung apa yang ada di dalam hidupnya setelah kematiannya. Menurut Al Azhari artinya menyambungkan sesuatu. Dinamakan wasiat, karena setelah meninggal dunia, mayit dapat menyambungkan apa yang ada saat dia hidup dengan wasiat itu. Menurut Ali Afandi, wasiat adalah suatu akta, suatu keterangan yang dibuat sebagai pembuktian campur tangannya seorang pejabat resmi.

Dalam syari'at, wasiat adalah penghibahan benda, piutang, atau menfaat oleh seorang kepada orang lain dengan ketentuan bahwa orang yang diberi wasiat memiliki hibah tersebut setelah kematian orang yang berwasiat.Sebagian ulama mendefinisikan wasiat sebagai pemberian kepemilikan yang didasarkan kepada masa setelah kematian. Dalam Kompilasi Hukum Islam pasal I7I huruf F, wasiat adalah pemberian suatu benda dari pewaris kepada orang lain atau lembaga yang akan berlaku setelah pewaris meninggal dunia.

Dalam buku Hukum Kewarisan Islam sebagai Pembaruan Hukum Positif di Indonesia, wasiat adalah pesan terakhir dari seseorang yang medekati kematianya, dapat berupa pesan tentang apa yang harus dilaksanakan para penerima wasiat terhadap hasrat peninggalannya atau pesan lain di luar harta peninggalan. Di dalam Kitab Undang-Undang Hukum Perdata pasal 875 menyebutkan bahwa surat wasiat atau testamen adalah sebuah akta berisi peryataan seseorang tentang apa yang dikehendakinya terjadi setelah ia meninggal, yang dapat dicabut kembali olehnya. Sedangkan dasar hukum wasiat dalam Al-Qur'an surah AlBaqarah ayat 180 dan Surah Al-Maidah ayat 106. Firman Allah SWT:

Yang artinya: Diwajibkan atas kamu, apabila seorang di antara kamu kedatangan (tanda-tanda) maut, jika ia meninggalkan harta yang banyak, Berwasiat untuk ibu-bapak dan karib kerabatnya secara ma'ruf, (ini adalah) kewajiban atas orang-orang yang bertakwa. (Qs. Al-Baqarah [2]: 180)

Dan hadits Rasulullah SAW:

Artinya: Abdullah bin Umar r.a meriwayatkan bahwa Rasulullah SAW bersabda: "tidak dibenarkan seorang muslim yang mempunyai suatu wasiat melewatkan dua malam kecuali wasiatnya itu ditulis di sisinya." ( HR. Bukhari, Kitab: "Wasiat" (55), Bab: Wasiat (I)

Berdasarkan keterangan di atas dapat disimpulkan bahwa wasiat merupakan syari'at Islam yang mempunyai fungsi bagi manusia, sehingga tak ada seorang ulama atau orang Islam yang menentang dengan adanya wasiat, bahkan perbuatan ini banyak dilakukan oleh umat Islam masa lalu. Pelaksanaan wasiat tidak hanya diatur dalam hukum Islam dan $\mathrm{KHI}$, hukum Barat yang berlaku di Indonesia yang tertuang dalam
Kitab Undang- Undang Hukum Perdata juga mengatur tentang wasiat. Muhammad Sayyid Sabiq menyatakan syarat-syarat wasiat adalah terdapat orang yang berwasiat, orang yang diberi wasiat, dan sesuatau yang diwasiatkan. Menurut Abdul Ghafur Ansori dan Yulkarnain Harahab, unsur-unsur yang terdapat dalam wasiat itu ada empat macam, yang meliputi orang yang berwasiat, orang yang menerima wasiat, sesuatau yang diwasiatkan, dan Sigat/lkrar.

Menurut Tamakiran, Syarat-syarat menjadi orang saksi dalam pembuatan atau penyerahan suatu testament kepada seorang notaris adalah: sudah dewasa, penduduk Indonesia, paham mengerti akan bahasa yang digunakan dalam testament tersebut. Sedangkan syarat-syarat untuk membuat testament, orang tersebut haruslah: telah berumur 18 tahun, telah dewasa (sudah kawin, walapun belum berusia 18 tahun), dan berakal sehat.

Dalam Kompilasi Hukum Islam seseorang yang akan berwasiat dijelaskan pada Pasal 194 yang berbunyi:

I) Orang yang telah berumur sekurang-kurangnya 2I tahun. Berakal sehat dan tanpa adanya paksaan dapat mewasiatkan sebagian harta bendanya kepada orang lain atau lembaga.

2) Harta benda yang diwasiatkan harus merupakan hak dari pewasiat.

3) Pemilikan terhadap harta benda seperti dimaksud dalam ayat I pasal ini baru dapat dilaksanakan sesudah pewasiat meninggal dunia.

Dalam kompilasi hukum Islam pasal 194 di atas, terlihat sangat jelas bahwa seseorang yang akan melakukan wasiat yang mempunyai kekuatan hukum yang kuat di Indonesia berumur sekurang-kurangnya 21 tahun, apabila seseorang melakukan wasiat yang belum cakap umur menurut Kompilasi Hukum Islam maka wasiatnya batal. Sedangkan di dalam Kitab Undang-Undang Hukum Perdata menyebutkan di dalam pasal 897 Bab Ketiga Belas, bagian kedua tentang kecakapan seseorang untuk membuat surat wasiat atau untuk memiliki keuntungan dari surat wasiat yang demikian. Berbunyi; anak-anak dibawah umur yang belum mencapai umur 18 tahun penuh, tak diperkenankan membuat surat wasiat.

Dalam Kompilasi Hukum Islam Pasal 194 Ayat (I) tentang batas usia orang yang berwasiat berbeda dengan Kitab Undang-Undang Hukum Perdata Pasal 897. Dari pernyataan yang telah dipaparkan dalam latar belakang tersebut di atas, mengapa dalam Kompilasi Hukum Islam menyaratkan batas usia berwasiat sekurang-kurangnya 21 tahun sedangkan di dalam Kitab Undang-Undang Hukum Perdata menyebutkan sekurang-kurangnya adalah 18 tahun. 


\section{PEMBAHASAN}

\section{Fase-Fase Perkembangan Usia Dewasa Menurut Psikologi}

a. Usia |3-2| tahun

Remaja adalah mereka yang mengalami masa transisi (pralihan) dari masa kanak-kanak menuju masa dewasa, yaitu antara usia 12-13 tahun hingga 20 tahun. Perubahan yang terjadi termasuk drastis pada hampir semua aspek perkembangan, yaitu meliputi perkembangan fisik, kognitif, kepribadian, dan sosial. Batasan usia remaja yang umum digunakan oleh para ahli adalah antara 12 hingga 2 I tahun. Rentang waktu usia remaja ini biasanya dibedakan atas tiga, yaitu: $12-15$ tahun= masa remaja awal, $15-18$ tahun = masa remaja pertengahan, dan I8-2I tahun= masa remaja akhir. Tetapi, Monks, Knoers dan Haditono, (200I) membedakan masa remaja atas empat bagian, yaitu: (1) masa pra-remaja atau pra-pubertas (10-12 tahun), (2) masa remaja wal atau pubertas adan masa remaja akhir (I8-2I). Remaja awal hingga remaja akhir inilah ini lah yang mabuat masa adolesen.

Pada masa adolesensi ini terjadi proses pematangan fungsi-fungsi psikis dan fisik, yang berlangsung secara berangsur-angsur dan teratur. Masa tersebut merupakan kunci penutup dari perkembangan anak. Pada periode ini anak muda banyak melakukan introspeksi (wawas diri) dan merenungi diri sendiri. Akhirnya anak bisa menemukan Aku-nya. Dalam pengertian: dia mampu menemukan keseimbangan dan harmoni/keselarasan baru di antara siakap kedalam diri sendiri dengan siakap keluar, kedunia obyektif.

Menurut banyak ahli ilmu jiwa, batas waktu adolesensi itu ialah 17-19 tahun, atau |7-2| tahun. Perbedaan karakteristik tiga fase prapubertas/pueral, pubertas (awal), adan adolesensi atau pubertas akhir itu antara lain ialah sebagi berikut:

I) Pada masa pra-pubertas (masa negatif, Vemeinung, Trotzalter kedua), anak sering merasakan: bingung, cemas, takut, gelisah, gelap hati, bimbang ragu, risau, sedih hati; rasa-rasa minder, melawan rasa-rasa "besar dewasasuper", dan lain-lain. Anak tidak tau sebabmusabab dari macam-macam perasaan kontradiktif yang menimbulkan banyak kerisaun hatinya.

2) Pada masa pubertas: anak mudam menginginkan/mendambakan sesuatu, dan mencari-cari sesuatu. Namun sebanarnya "sesuatu" yang diharapkan dan dicari itu, dia sendiri tidak tahu. Anak muda sering merasa sunyi di hati, dan menduga ia tidak mengerti orang lain dan tidak mengerti oleh pihak luar.

3) Pada masa adolesensi: anak muda merasa mantap, stabil. Dia mulai mengenal Aku-nya, dan dan ingin hidup dengan pola hidup yang digariskan sendiri, dengan etikat baik dan keberanian. Dia mulai memahami arah hidupnya. la mempunyai pendirian tertentu berdasarkan suatu pola hidup yang jelas yang beru ditemukannya.

b. Usia 21-40 tahun masa perkembangan orang dewasa Perkembangan usia yang dimana masa dewasa yang dimulai dari beberapa masa diantaranya ialah: masa dewasa awal: 18-40 tahun, masa dewasa madya: 4060 tahun, dan masa dewasa akhir: 60- tahun sampai meniggal dunia. Menurut Freud (Bischof: 1976), seseorang dikatakan dewasa apabila orang itu bertanggung jawab terhadap pekerjaan sehari-hari dan adanya rasa cinta yang telah diikrarkan, khususnya kepada pasangan pernikahan. Freud juga menjelaskan bahwa seseorang dikatakan dewasa apabila mau dan mampu bertanggung jawab terhadap segala tingkah laku, pekerjaan, dan karir yang dilakukan sehari-hari.

Dengan demikian, orang dewasa dituntut untuk mempertanggungjawabkan semua yang dilakukan, bekerja memenuhi kebutuhan dirinya dan kehidupan keluarga sebagai wujud cinta terhadap istri dan anakanaknya. Orang dewasa yang matang tidak lagi merasa takut terabaikan kepentingan dirinya sendiri dalam proses mempertanggungjawabkan cinta yang diikrarkan.

Pembagian masa dewasa menurut Elizabeth B. Hurlock membagi masa dewasa menjadi tiga bagian:

a. Masa dewasa awal ( masa dewasa dini/young adult)

Masa dewasa awal adalah masa pencarian kemantapan dan masa produktif yaitu suatu masa yang penuh dengan masalah ketegangan emosional, priode isolasi sosial, priode komitmen dan masa ketergantungan, perubagan nilai-nilai, kreativitas dan penyesuaian diri pada pola hidup yang baru. Kisaran umur antara 21 sampai 40 tahun.

b. Masa dewasa madya (Middle Adulthood)

Masa dewasa madya ini berlangsung dari umur 40 samapai 60 tahun. Ciri-ciri yang menyangkut pribadi dan sosial antara lain; masa madya merupakan masa transisi, di mana pria dan wanita meninggalkan ciri-ciri jasmani dan pelaku masa dewasanya dan masuki suatu priode dalam kehidupan dengan ciri-ciri jasmani dan pelaku 
yang baru. Perhatian terhadap agama lebih besar dibandingkan dengan masa sebelumnya, dan kadang-kadang minat dan perhatiannya terhadap agama ini dilandasi kebutuhan pribadi dan sosial.

c. Masa dewasa lanjut (Masa tua/Older Adult)

Usia lanjut adalah periode penutup dalam rentang hidup seseorang. Masa ini dimulai dari umur 60 tahun sampai akhir hayat, yang ditandai dengan adanya perubahan yang bersifat fisik dan psikologis yang semakin menurun. Adapun ciriciri yang berkaitan dengan penyesuaian pribadi dan sosialnya sebagai berikut: perubahan yang menyangkut kemampuan motorik, kemampuan fisik, perubahan dalam fungsi psikologis, perubahan dalam sistem saraf, dan penampilan.

Dari uraian di atas tentang pengertian dan pembagian tahapan kedewasan maka selanjutnya dilanjutkan dengan ciri-ciri kedewasaan seseorang menurut ahli psikologi diantaranya adalah. Secara psikologis kedewasaan adalah keadaan di mana sudah ada ciri-ciri psikologis tertentu pada seseorang. Ciri-ciri psikologis itu menurut G. W. Allport (196I) adalah:

a. Pemekaran diri sendiri (extension of the self), yang ditandai dengan kemampuan seseorang untuk menganggap orang atau hal yag lain sebagai bagian dari dirinya sendiri juga. Perasaan egoisme (memerintahkan diri sendiri) berkurang, sebaliknya tumbuh perasaan ikut memiliki. Salah satu tanda yang khas adalah tumbuhnya kemampuan untuk mencintai orang lain dan alam sekitarnya. Kemampuan untuk menenggang rasa dengan orang yang dicintainya, untuk merasakan penderitaan yang dialami oleh orang yang dicintainya itu menujukkan adanya tanda-tanda kepribadian yang dewasa (mature personality). Di samping itu, juga adalah berkembang ego ideal berupa cita-cita, idola dan sebagainya yang menggambarkan bagaimana wujud ego (diri sendiri) di masa depan.

b. Kemampuan untuk melihat diri sendiri secara objektif (self objectivication) yang ditandai dengan kemampuan untuk mempunyai wawasan tentang diri sendiri (self insight) dan kemampuan untuk menangkap humor (sense of humor) termasuk menjadikan dirinya sendiri sebagai sasaran. la tidak marah jika dikeritik dan di saat-saat yang diperlukan ia bisa melepaskan diri dari dirinya sendiri dan meninjau dirinya sendiri sebagai orang luar.

Memiliki falsafah hidup tetentu (unifying philosophy of life). Hal ini dapat dilakukan tanpa perlu merumuskannya dan mengucapkanya dalam katakata. Orang yang sudah dewasa tahu dengan tempatnya dalam kerangka susunan objek-objek lain dan manusia-manusia lain di dunia. la tahu kedudukannya dalam masyarakat dalam masyarakat, ia paham bagaimana seharusnya ia bertingkah laku dalam kedudukan tersebut dan ia berusaha mencari jalannya sendiri menuju sasaran yang ia tetapkan sendiri. Orang seperti ini tidak lagi mudah terpengaruh dan pendapat-pendapat serta sikapsikapnya cukup jelas dan tegas.

\section{Batasan Usia Pewasiat Menurut Hukum Islam}

la tidak boleh mewasiatkan apa yang sebelumnya telah diwasiatkan kepadanya. la tidak boleh menjual atau membelanjakan harta mereka untuk kepentingan pribadi, yang mana hal tersebut hanya diperbolehkan untuk bapaknya. Harta anak-anak orang gila tidak boleh dikelola kecuali oleh orang tuanya, penerima wasiat atau hakim. Hendaknya para wali meyerahkan harta kepada anak-anak yang mulai baligh untuk menguji kedewasaannya. Dewasa di sini dalam artian bisa mengelola harta. Anak-anak yang sudah tampak kedewasaannya maka seharusnya diserahkan kepadanya, di saat ia sudah baligh, kemudian dipersaksikan baik laki-laki maupun perempuan. Jika ia kembali tampak kebodohannya dalam pengelola harta maka harta tersebut kembali ditarik dari tangannya. Berikutnya yang mengatur hartanya adalah hakim. Harta tetap ditahan sampai ada keputusan dari hakim.

Disyaratkan agar orang yang memberi wasiat adalah orang yang ahli kebaikan, yaitu orang yang mempunyai kopetensi (kecakapan) yang sah. Keabsahan kopetensi ini di dasarkan pada akal, kedewasaan, kemerdekaan, ihtiar, dan tidak dibatasi karena keduguan atau kelalaian. Apabila memberi wasiat pemberi wasiat itu orang yang kurang kopetensinya, yaitu kerana anak-anak, gila, hamba sahaya, dipaksa, atau dibatasi; wasiatnya itu tidak sah. Adapun syarat-syarat sah orang yang berwasiat (mushii) adalah berkompeten melakukan Tabarru', yaitu mukallaf (baligh dan berakal sehat), merdeka, baik lakilaki maupun perempuan, Muslim maupun kafir.

Berakal adalah syarat yang sudah disepakati dalam hal wasiat. Karena itu, wasiat yang keluar dari orang gila, orang idiot, dan orang yang epilepsi tidak sah. Kerana, ungkapan (ucapan) mereka tidaklah dianggap dan hukum tidak berhubungan dengan ungkapan tersebut. Para ulama fiqih menyaratkan orang yang berwasiat (mushii) harus orang yang merdeka. Maka, wasiat yang keluar seorang budak tidaklah sah; karena wasiat adalah tabarru'. Sedangkan, budak bukan orang yang berkopeten dalam hal tabarru', dan juga karena dia tidak 
memiliki apa pun hingga dia bisa memberikan kepemilikannya kepada orang lain.

Golongan Hanfiyyah sepakat, dan golongan Syafi'iyyah dalam satu pendapat yang lebih unggul dua pendapat yang ada menyaratkan orang yang berwasiat (mushii) haruslah orang yang sudah baligh. Artinya, tidak sah wasiat yang keluar dari anak kecil yang sudah atau belum tamyiz, meskipun si tamyiz sudah di izinkan untuk menjalankan perdagangan. Karena, wasiat termasuk tasharruf yang mengandung bahaya murni, karena ia adalah sebuah tabarru',dan wasiat juga tidak termasuk pekerjaan perdagangan.

Golongan Malikiyyah dan Hanabilah memperbolehkan wasiat yang dilakukan anak yang sudah tamyiz, yang sudah berusia sepuluh tahun atau kurang sedikit, yang terdapat di dalam Muwathha' Al Imam Malik r.a.:

Yang artinya: Bersumber dari Abdullah bin Bakar bin Hazem, dari bapaknya, sesungguhnya Amer bin Sulaim Az Zuraqi bercerita kepadanya, bahwa pernah dilaporkan kepada Umar bi Khaththab: "Sesungguhnya di sini ada seorang bocah yang belum baligh dan belum pernah bermimpi mengeluarkan air mani, sedang para warisnya berada di Syam. Bocah itu punya harta dan di sini ia hanya tinggal bersama puteri pamannya". Umar bin Khathtab mengatakan: "Hendaklah dia mewasiatkan kepada saudara sepupu itu”. Si bocah tadi pun mewasiatkan hartanya berupa sebuah sumur berukuran besar. Kata Amer bin Sulaim lebih lanjut, harta tersebut kemudian dijual seharga tiga puluh ribu dirham. Puteri pamannya yang diberikan wasiat tadi ialah, ibunya Amer bin Az Zuraqi sendiri."

Jika si tamyiz ini memikirkan qurbah (pendekatan diri kepada Allah). Karena wasiat merupakan tasharruf yang murni manfaat, maka sah dilakukan oleh anak yang sudah tamyiz seperti halnya Islam dan shalat yang dilakukannya. Golongan Hanafiyyah juga memperbolehkan wasiat anak yang sudah tamyiz (berusia sempurna tujuh tahun), jika wasiatnya berisi tentang pengurusan, pengafanan, dan penguburannya; karena Umar r.a. memperbolehkan wasiat anak kecil dari suku Ghassan yang berusia sepuluh tahun dari paman jalur ibu, dan diperbolehkannya wasiat anak kecil karena dalam wasiat tidak ada unsur bahaya. Sebab, harta akan menjadi miliknya selama dia masih hidup. Dia boleh saja mencabut wasiatnya.

Menurut peneliti dari uraian di atas menujukan bahwa syarat sahnya wasiat adalah orang yang sudah (baligh dan berakal sehat), merdeka, baik laki-laki maupun perempuan, Muslim maupun kafir. Baligh ialah orang yang sudah mencapai batasan dalam usia tertentu. apabila seseorang itu mampu untuk membedakan mana yang baik dan mana yang batil dan dapat berfikir yang lebih luas dan dapat berfikir yang mulai rumit. Adapun menurut Golongan Malikiyyah yang memperbolehkan orang yang berwasiat adalah anak yang tamyiz umur tujuh tahun, menurut peneliti dari beberapa pendapat tentang batsan usia berwasiat adalah lebih mengambil pendapat yang sudah baligh karena diusia tersebut sudah cara berfikir yang lebih luas dan dapat mepertanggung jawabkan apa yang dibuat karena usia perkembangan anak berbeda-beda dalam tehapan kedewasaan. Sifat yang terkendali dalam tidak mengelola kekayaan. "Oleh karena itu, ar-rusyd, kita terjemahkan ke bahasa Indonesia dengan kematangan.

Dilihat dalam kehidupan sehari-hari, anak berusia 15 tahun (anak SMP) belum begitu matang dalam berpikir, apalagi untuk bertindak menyangkut kekayaan. Oleh kerana itu, untuk menentukan kedewasaan dalam lapangan hukum kekayaan (muamalah maliah), pada pendapat Hanafi bahwa dewasa itu adalah ketika seseorang "genap berusia 18 tahun dan memasuki 19 tahun, karena pada saat itu anak telah matang secara fisiologis dan psikologis, tanpa membedakan antara lakilaki dan perempuan kerana seperti kata al-Mawardi (w.450/l058) tidak ada dasar pembedaan itu. Ini sesuai pula dengan adat kebiasaan (uruf) yang berlaku dalam masayarakat kita sekarang yang menganggap kematangan itu mencapai pada usia 18 tahun. Mengenai usia tamyiz dalam fikih dinyatakan mulai sejak usia tujuh tahun. Ketentuan ini juga harus dipandang sebagai tamyiz dalam kaitan dengan masalah ibadah. Untuk lapangan harta kekayaan, diperlukan usia yang lebih besar, tetapi belum matang (ar-rusy), yaitu usia 12 tahun hingga 18 tahun. Hal ini didasarkan pada pendapat dalam al Mugni bahwa anak dapat melakukan tindakan yang murni menguntungkan pada usia 12 tahun. Sementara itu, anak berusia kurang dari 12 tahun dipandang sebagai anak-anak. Ini sejalan dengan pula dengan ijtihad hukum Islam di Indonesia seperti tercantum dalam Pasal 105 Kompilasi Hukum Islam di Indonesi (KHI).

Jadi pereodesasi hidup manusia dalam kaitan dengan tingkatan kecakapan hukum dalam lapangan hukum harta kekayaan adalah (I) priode janin, di mana sejak hukum memiliki kecakapan menerima hukum tidak sempurna, (2) periode kanak-kanak, yaitu usia 0 tahun hingga II tahun, dimana ia memiliki kecakapan menerima hukum sempurna, hanya untuk kewajiban terbatas, (3) anak mumayiz, yaitu usia 12 tahun hingga genap I 8 tahun, dimana ia memiliki kecakapan bertindak hukum tidak sempurna disamping menerima hukum yang sempurna, (4) orang berusia genap 18 tahun (memasuki 19 tahun) adalah orang dewasa dan memiliki kecakapan menerima hukum sempurna. 
Menurut penulis mengenai batasan usia orang yang berwasiat berpatokan pada usia yang baligh dan berakal sehat, adapun di dalam Kompilasi Hukum Islam yang di sebutkan pada Pasal 194 ayat I mengenai batasan orang yang berwasiat telah berumur sekurang-kurangnya 21 tahun, berakal sehat dan tanpa adanya paksaan dapat mewasiatkan sebagaimana harta bendanya kepada orang lain atau lembaga. Menurut Samsul Anwar bahwasanya orang berusia genap 18 tahun (memasuki 19 tahun) adalah orang dewasa dan memiliki kecakapan menerima hukum sempurna, dari terlihat bawa di masyarakat Indonesia umur 19 tahun adalah umur setandar dewasa adapun umur $2 \mathrm{I}$ satu tahun setandar untuk melakukan wasiat adalah ijtihat dari Hukum Islam di Indonesia $(\mathrm{KHI})$ untuk kemaslahatan dan berpatokan pada pasal 426 KUH Perdata.

Pada usia berapakah seseorang dapat melakukan wasiat? Dan apa saja ketentuan mengenai hal itu? Seseorang dapat melakukan wasiat sekurang-kurangnya pada usia 2I tahun, dengan syarat ia berakal sehat dan tidak ada paksaan. Sedang harta yang diwasiatkan merupakan hak dari pewasiat sendiri. Pelaksanaannya setelah pewasiat meninggal dunia.

3. Konsepsi Taklif dan Mukallaf dalam Hukum Islam

Taklif ialah tuntutan pelaksanaan beban tugas yang sudah ditentukan. Mukallaf ialah orang yang memikul tanggung jawab terhadap beban tugas pelaksanaan hukum taklifi. Mukallaf disebut juga dengan istilah mahkum'alaih.Dasar adanya taklif kepada mukallaf ialah karena adanya akal dan kemampuan memahami padanya. Saifudin al-Amidi menegaskan, bahwa telah sepakat para ulama tentang syarat mukallaf yaitu haruslah berakal dan mampu memahami. Karena sumber taklif adalah khitab (firman, sabda). Suatu firman yang dihadapkan kepada orang yang tidak berakal dan tidak dapat memahami tinggkat dasar, seperti baru dapat memahami kandungannya yang mengandung perintah atau larangan, yang berpahala atau berdosa, dan yang memerintahkan itu adalah Allah yang wajib ditaati, maka orang yang seperti itu orang gila dan anak-anak yang belum mamapu membedakan sesuatu. Orang-orang yang demikian tidak ada baginya taklif.

Adapun anak-anak yang sudah mumayyiz (mampu membedakan) meskipun ia sudah mempunyai kemampuan memahami namun masih jauh dari sempurna tentang wujud Allah dengan sifat-sifat-Nya yang sempurna; tentang adanya Rasul yang bersifat benar dan menyampaikan ajaran Allah dan sebagainya yang berhubungan dengan pemahaman taklif. Sangat sulit mengetahui kematangan itu adalah secara berangsurangsur, dan tidak ada suatu pertanda yang tepat untuk itu kecuali baligh. Sabagai dalilnya ialah peryataan Rasulullah:

Artinya: Diadakan hukum dari tiga orang. lalah dari anak-anak sehingga usia baligh, dari orang tidur hingga ia bangun, dan dari orang gila sehingga sehat kembali.

Menurut keterangan Al-Amidi.

a. Yang menjadi dasar taklifi itu ialah akal karena taklif itu bersumber pada firman yang harus dipahami oleh akal

b. Akal tumbuh berkembang secara berangsur-angsur semenjak usia muda, dan dipandang belum sampai ke batas taklif melainkan jika akal sudah mencapai kesempuranaan dalam pertumbuhannya.

c. Pertumbuhan secara berangsur-angsur ini terjadi masa kemasa secara tersembunyi sehingga baru jelas permulaan kesempurnaanya (kematangannya) jika sudah mencapai masa baligh. Sebagai batas masa pemisah antara masa masih kurang sempurna akal dengan mulai mencapai kesempurnaanya ialah baligh. Dikala seseorang sudah baligh termasuk ia dalam katagori mukallaf. Dan setiap mukallaf harus betanggung jawab terhadap hukum taklifi.

Peran akal merupakan faktor utama dan syari'at Islam untuk menentukan seseorang sabagai mukallaf. Karena itu meskipun seseorang sudah mecapai usia baligh tetapi akalnya tidak sehat maka hukum taklifi tidak dibebankan kepadanya. Ulama usul menetapkan bahwa syarat pembebanan hukum ialah kemampuan si mukallaf untuk melaksanakannya. Karenanya, sesuatu yang tidak sanggup dikerjakan si mukallaf, tidak tidak boleh dibebankan, baik menurut syara' maupun akal. Demikianlah menurut pendirian golongan Hanafiah dan Mu'takzilah. Apabila kita temukan nash syara' yang mengharuskan kita mengerjakan sesuatu tidak sanggup kita kerjakan, maka hukum itu haruslah dilihat kepada hal-hal yang mendahuluinya, atau pada hal-hal yang berkaitan ataupun kepada qarinah-qarinah-nya.

Ulama membagi masa yang dilalui oleh manusia sampai mereka menjadi mukallaf yang sebenarnya, kepada:

a. Masa janin masih dalam kandungan.

b. Masa setelah lahir dan sebelum mumayyiz.

c. Masa telah mumayyiz.

d. Masa dewasa.

Ketika dalam kandungan seseorang mempunyai keahlian menerima tidak penuh dan tidak mempunyai keahlian berbuat sama sekali. Setelah ia lahir dan menjelang tamyiz barulah ia memiliki keahlian berbuat, tetapi belum sempurna. Adakalanya pembuatannya berhubungan dengan hak Allah, seperti sholat, puasa, dipandang sah bila cukup rukun dan syaratnya, tidak wajib baginya menyelesaikannya. Adapun yang berhubungan dengan hak manusia terbagi kepada: 
a. Yang menguntungkan dapat dilakukan tanpa izin walinya, seperti menerima pemberian.

b. Yang merugikan tidak dapat dilakukan, meskipun dengan izin walinya, misalnya memberikan suatu harta.

c. Yang ada rugi dan untungnya, boleh dilakukan setelah izin walinya, seperti jual beli.

Setelah dewasa manusia itu mempunyai keahlian (ahliyat) berbuat sepenuhnya, baik berhubungan dengan hak Allah, hak hamba, ibadah, dan mu'amalah. Pada masa inilah mereka menjadi mukallaf yang sebenarnya. Menurut peneliti, dari uraian di atas bahwasannya pembebanan hukum kepada mukallaf adalah mukallaf yang telah baligh/dewasa yang akalnya sehat yang sudah mampu membedakan antara yang banar ataupun yang salah yang dapat melakukan perintah Allah dan menjauhi laranganya, dan mampu melaksanakan perintah antara manusia dengan manusia adapun dalam batasan usia dimulai dari umur 10-16 tahun yang dimana masa tersebut adanya perbedaan setiap orang.

4. Batasan Usia Pewasiat Menurut Kitab UndangUndang Hukum Perdata

Pembuatan wasiat umum dirumuskan sebagaimana halnya suatu akta berita acara. Bahkan naskah yang keluar dari mulut pembuat wasiat diletakan di antara tanda kutip. Setelah naskah tersebut dibacakan maka notaris menanyakan kepada pembuat wasiat apakah yang dibacakan itu mengandung kehendak terakhirnya. Notaris harus menyakinkan diri agar ia memperoleh jawaban yang jelas. Bandingkan pasal 986 BW (Pasal 939 KUHPerdata).

Oleh sebab itu, notaris wajib menilai kemampuan pembuat wasiat membentuk kehendaknya. Untuk itu, ia seringkali perlu meminta bantuan seorang ahli. Penanda tanganan wasiat notaris membuktikan secara lengkap (kecuali dibuktikan kebalikannya) bahwa pembuat wasiat tidak menguasai penyusunan redaksi yuridis, tidak tidak boleh di tarik kesimpulan bahwa ia tidak mampu menyampaikan naskah tersebut. Justru tugas notaris disini ialah menerjemahkan kehendak yang masih serba mentah ini ke dalam pengertian yuridis yang yang dapat dipertanggungjawabkan.

Dapatkah seorang yang tak cakap (secara hukum) membuat sebuah wasiat? Kenyataan bahwa seseorang ditaruh di bawah pengampuan, tidak berarti bahwa per definisi ia tidak memiliki kemampuan menentukan kehendaknya. Oleh sebab itu, pasal 944 BW (pasal 897 KUHPerdata) hanya menolak kewenangan membuat wasiat bagi mereka yang ditaruh di bawah pengampuan yang di rundung ganguan jiwa. Tetapi meraka yang dirundung gangguan jiwa pun pada saat-saat tertentu dapat mengalami kecerahan dalam menggunakan akal.
Inilah yang menyebabkan adanya suara-suara yang menghendaki larangan yang terkandung dalam pasal 944 BW (pasal 879 KUHPerdata) dan begitu pula dengan latar belakang Traktat Eropa tentang perlindungan hakhak asasi manusia dan kebebasan-kebebasan fundamental. Cukup kiranya di sini bahwa pasal 942 BW (pasal 895 KUHPerdata) mengajukan sebagai syarat memiliki kemampuan mentukan kehendaknnya. Demikian pula seseorang yang ditaruh di bawah pengampuan (curandus) harus dapat menggunakan akal sehatnya pada waktu membuat wasiat. Dilihat dari batasan usia wasiat yang terdapat di dalam (Pasal 897 KUHPerdata) menyebutkan bahwa, Anak-anak di bawah umur yang belum mencapai umur delapan belas tahun penuh, tidak diperkenankan membuat surat wasiat.

Dengan batasan umur delapan belas tahun penuh dikarenakan syarat orang yang cakap dalam berbuat hukum haruslah berakal sehat dan tidak pada pangampuan orang tua jadi dari sini lah tardapat suatu syarat orang yang mambuat wasiat haruslah sudah berumur delapan belas tahun penuh sesuai dengan pasal 426 KUH Perdata.

5. Kedewasaan dan Kecakapan Hukum menurut Hukum Positif

a. Kecakapan/ pendewasaan menurut KUHPerdata dalam membuat Testament.

Pendewasaan ada dua macam, pendewasaan penuh pendewasaan untuk beberapa perbuatan hukum tertentu (terbatas). Keduanya harus memenuhi syarat yang ditetapkan undang-undang untuk pendewasaan penuh syaratnya telah berumur 20 tahun. Adapun pendewasaan terbatas syaratnya sudah berumur 18 tahun penuh (Pasal 42I dan 426 KUHPerdata).

Untuk kedewasaan penuh, prosedurnya adalah yang bersangkutan mengajukan permohonan kepada Presiden RI dilampiri dengan akta surat kelahiran atau alat bukti lainya. Setelah mendengar pertimbangan Mahkamah Agung, Presiden memberikan keputusannya. Akibat hukum adanya pernyataan pendewasaan penuh adalah setatus hukum yang bersangkutan sama dengan status hukum orang dewasa. Apabila ingin melangsungkan perkawinan, izin orang tua tetap diperlukan.

Untuk pendewasaan terbatas, prosedurnya adalah yang bersangkutan mengajukan permohonan kepada Ketua Pengadilan Negeri yang berwenang di lampiri akta kelahiran atau surat bukti lainya. Setelah mendengar keterangan orang tua atau wali yang bersangkutan, pengadilan memberikan ketetapan pernyataan dewasa dalam perbuatan-perbuatan hukum tertentu sesuai dengan yang dimohonkan, 
misalnya perbuatan mengurus dan menjalankan perusahaan, membuat surat wasiat. Akibat hukum pernyataan dewasa terbatas adalah status hukum yang bersangkutan sama dengan status hukum orang dewasa untuk perbuatan-perbuatan hukum tertentu.

I) Pendewasaan menurut para ahli

a) Riduan Syahrani: pendewasaan merupakan suatu cara untuk meniadakan keadaan belum dewasa terhadap orang-orang yang belum mencapai umur 21 tahun. Memberikan kedudukan hukum (penuh atau terbatas) sebagai orang dewasa kepada orang-orang yang belum dewasa. Pendewasaan penuh hanya diberikan kepada orang-orang yang telah mencapai usia 18 tahun, yang diberikan dengan keputusan Pengadilan Negeri.

b) Subekti: pendewasaan adalah suatu pernyataan tentang seseorang yang belum mencapai dewasa sepenuhnya atau hanya untuk beberapa hal dipersamakan dengan seorang yang sudah dewasa.

c) Abdul Kadir Muhammad: pendewasaan adalah suatu upaya hukum yang di gunakan untuk meniadakan keadaan belum dewasa, baik keseluruhan maupun hal-hal tertentu.

2) Kedewasaan dan Pendewasaan

Istilah "kedewasaan" menunjuk pada keadaan dewasa memenuhi syarat hukum. Istilah "Pendewasaan" menunjuk pada keadaan belum dewasa oleh hukum dinyatakan sebagai dewasa. Untuk memahami konsep dewasa atau belum dewasa perlu dibaca Pasal KUHPerdata, Stb. Nomor 556 Tahun 1924, Nomor 557 Tahun 1924. Menurut ketentuan KUHPerdata, belum dewasa (minderjarig) adalah belum berumur 21 tahun penuh dan belum pernah kawin. Apabila mereka yang kawin sebelum berumur 21 tahun penuh bercerai, mereka tidak kembali lagi dalam keadaan belum dewasa (Pasal 330 KUHPerdata). Dalam Staatsblad yang berlaku bagi orang Timur Asing seperti yang diyatakan di atas tadi, apabila dalam perundang-undangan dijumpai istilah "belum dewasa" (minderjarig), berarti belum berumur 21 tahun itu bercerai, mereka tidak kembali lagi dalam keadaan belum dewasa.

Berdasarkan ketentuan di atas dapat dipahami acontrario orang dewasa (meerderjarig), yaitu orang yang sudah berumur 21 tahun penuh walaupun belum berumur $2 \mathrm{I}$ tahun penuh, tetapi sudah kawin. Demikian juga acontrario jika dalam perundang-undangan dijumpai istilah "dewasa" (meerderjarig) itu berarti sudah berumur 2I tahun penuh dan walaupun belum berumur 2 Itahun penuh, tetapi sudah kawin. Keadaan dewasa yang memenuhi syarat undang-undang ini disebut "kedewasaan". Orang dewasa atau dalam kedewasaan cakap atau mampu (bekwaam, capable) melakukan perbuatan hukum, misalnya, membuat perjanjian, melakukan perkawinan, dan membuat surat wasiat. Kecakapan hukum ini berlaku penuh selama tidak ada keadaan yang mempengaruhi atau membatasinya, antara lain, sakit ingatan, dungu, dan pemboros.

Menurut peneliti dari uraian tentang batasan kecakapan dan pendewasaan berbeda kerena kecakapan hanya pada tanggung jawab pada apa yang ia perbuat adapun kedewasaan pertanggung jawabannya lebih banyak dan dalam hal berfikir sudah memikirkan masa depan yang sudah diperkirakan. Dalam kecakapan/dewasa batasan umur setiap orang berbeda-beda tetapi Kitab Undang-Undang Hukum Perdata sudah menentukan hukum orang yang cakap hukum dan dewasa adalah berumur 18 tahun.

b. Kecakapan/ pendewasaan menurut Hukum Perjanjian Dalam Bertindak Hukum.

Kecakapan (bekwaamheid-capacity) yang dimaksud dalam pasal I 320 BW syarat 2 adalah kecakapan untuk melakukan perbuatan hukum. Cakap untuk melakukan perbuatan hukum diartikan sebagai kemungkinan untuk melakukan perbuatan hukum secara mandiri yang mengikat diri sendiri tanpa dapat diganggu gugat. Kecakapan untuk melakukan perbuatan hukum pada umumnya diukur dari standar, berikut ini:

I) Person (pribadi), diukur dari standar usia kedewasaan (meerderjarig).

2) Rechtspersoon (badan hukum), diukur dari aspek kewenangan (bevoegheid).

Kecakapan untuk melakukan perbutan hukum bagi person pada umumnya diukur dari standar usia dewasa atau cukup umur (bebkwaamheidmeerderjarig). Namum demikian, masih terdapat polemik mengenai kecakapan melakukan perbuatan hukum yang tampaknya mewarnai praktik lalulintas hukum dimasyarakat. Pada satu sisi bagian masyarakat masih menggunakan standar usia 21 tahun sebagai titik tolak kedewasaan seseorang dengan landasan Pasal 1330 BW jo. 330 BW. Sementara pada sisi lain mengacu pada standar usia 18 tahun, sebagaimana yang diatur dalam Pasal 47 jo. 50 Undang-Undang Nomor I Tahun 1974 tentang perkawinan. 
Dalam KUH Perdata terdapat dua istilah tidak cakap (Onbekwaam) dan tidak berwenang (Onvevoegd).

I) Tidak cakap adalah orang yang umumnya berdasar ketentuan undang-undang tidak mampu membuat sendiri perjanjian-perjanjian dengan akibat hukum yang lengkap, seperti orang belum dewasa, orang di bawah kuratil (pengampuan), sakit jiwa dan sebagainya.

2) Tidak berwenang adalah orang itu cukup tetapi ia tidak dapat melakukan perbuatan hukum tertentu misal pasal-pasal I467, I470, I60 I i, 167 dan I68I.

Hal-hal yang berhubungan dengan kecakapan dan kewenangan bertindak dalam rangka perbuatan untuk kepentingan diri pribadi perorangan diatur dalam pasal I329 sampai dengan pasal I33I Kitab Undang-Undang Perdata. Pasal 1329 Kitab UndangUndang Perdata menyatakan bahwa:

Setiap orang adalah cakap untuk membuat perikatanperikatan, jika ia oleh undang-undang tindak dinyatakan tidak cakap.”

Rumusan tersebut membawa arti positif, bahwa selain dinyatakan tidak cakap maka setiap orang adalah cakap dan berwenang untuk bertindak dalam hukum.

Pasal 1330, tidak cakap untuk membuat perjanjianperjanjian adalah:

I) Orang yang belum dewasa.

2) Mereka yang di bawah pengampuan.

3) Orang-orang perempuan, dalam hal yang ditetapkan oleh undang-undang dan pada umumnya semua orang pada siapa undangundang telah melarang membuat perjanjianperjanjian tertentu (substansi ini dihapus dengan SEMA Nomor 3 Tahun 1963 dan Pasal 31 Undang-Undang Nomor ITahun 1974 tentang perkawinan).

Pasal 330 BW menyatakan, bahwa:

Belum dewasa adalah mereka yang belum memcapai umur genap dua puluh satu tahun dan tidak kawin sebelumnya. Apabila perkawinan dibubarkan sebelum mereka genap dua puluh satu tahun, maka meraka tidak bersetatus belum dewasa. Mereka yang belum dewasa dan tidak dibawah kekuasaan orangtua, berbeda di bawah perwalian atas dasar dan dengan cara ini yang diatur dalam bagian 3,4,5 dan 6 dalam bab ini.

I) Penentuan tentang arti istilah "belum dewasa" yang mempergunakan dalam beberapa peraturan undang-undang terhadap penduduk Indonesia. Untuk menghilangkan keraguan-raguan yang disebabkan oleh adanya Ordonansi (Peraturan pemerintah) tanggal 21 Desember I 97I dalam S.

1917-738, maka Ordonansi (Peraturan pemerintah) ini di cabut kembali, dan ditentukan sebagai berikut: Bila peraturan-peraturan menggunakan istilah "belum dewasa" maka sejauh mengenai penduduk Indonesia, dengan istilah ini dimaksudkan semua orang yang belum genap 21 tahun dan yang sebelumnya tidak pernah kawin.

2) Bila perkawinan itu di bubarkan sebelum mereka berumur $2 \mathrm{I}$ tahun, maka mereka tidak kembali bersetatus belum dewasa.

3) Dalam pengertian perkawinan tidak termasuk perkawinan anak-anak.

Beberapa undang-undang yang menegaskan standar usia 18 tahun merupakan standar usia dewasa yang berkolerasi dengan kecakapan melakukan perbuatan hukum, antara lain:

I) Undang-Undang Nomor 3 Tahun 1997 tentang pengadilan Anak (vide Pasal 5 jo.6I),

2) Undang-Undang Nomor 30 Tahun 2004 tentang Peraturan Jabatan Notaris (vide Pasal 39 jo.30).

3) Undang-Undang Nomor 12 Tahun 2006 tentang kewarganegaraan Republik Indonesia (vide Pasal 5 jis.6,9,2I,22,4I).

Bahkan perkembangan di Belanda yang menjadi sunber rujukan standar kedewasaan untuk mengatur kecakapan seseorang sebagaimana diatur dalam Pasal 338 jo. 1366 BW Ned. (sama dengan 330 jo. I 330 BW), melalui ketentuan Pasal 2:33 NBW telah meninggalkan standar usia 21 tahun. Dengan mengunakan interprestasi a-contrario terhadap subtansi Pasal 2:33 NBW dapat disimpulkan telah menggunakan acuan usia 18 tahun sebagai standar usia dewasa (kecakapan untuk melakukan perbuatan hukum).

Dari uraian di atas tentang hukum perjanjian kaitanya pada hukum wasiat adalah memberikan harta benda pada ahli waris ataupun orang lain dan lembaga yang dimana pemberian tersebut terdapat perjanjian sehingga adanya kesepakatan antara dua belah pihak. Dalam penentuan usia hukum perjanjian adalah antara |8-2I tahun dapat dikatakan cakap bertindak hukum.

c. Kecakapan/ pendewasaan menurut Hukum Pidana Dalam Bertindak Hukum.

Anak adalah anak yang telah berumur 12 (dua belas) tahun, tetapi belum berumur 18 (delapan belas) tahun yang diduga melakukan tindak pidana. Anak yang menjadi korban tidak pidana yang disebut sebagi anak korban adalah anak yang belum berumur (delapan belas) tahun yang mengalami penderitaan 
fisik, mental, dan/atau kerugian ekonomi yang disebabkan oleh tidak pidana. Anak yang menjadi saksi adalah anak yang belum berumur (delapan belas) tahun yang dapat memberikan keterangan guna kepentingan penyidikan, penuntutan, dan pemeriksaan di sidang pengadilan tentang suatu perkara pidana yang digelar, dilihat, dan/atau dialaminya sendiri. Hakikatnya, ruang lingkup pengaturan Anak, Anak Saksi dan Anak Korban dalam SPPA adalah keseluruhan proses penyelesaian perkara $A B H$, mulai tahap penyidikan sampai dengan tahap pembibingan setelah menjalani pidana.

Dapat dipastikan bahwa terdakwa dalam sidang anak adalah anak nakal. Pengertian anak nakal ini ada dua kelompok yakni anak yang melakukan tidak pidana dan yang melakukan perbuatan yang terlarang bagi anak. Undang-undang Nomor 3 Tahun 1997 yang merumuskan anak nakal ini (Pasal I butir 2) yaitu sebagai berikut.

I) Anak yang melakukan tindak pidana; atau

2) Anak yang melakukan perbuatan yang dinyatakan terlarang bagi anak, baik menurut peraturan perundang-undangan maupun menurut peraturan hukum lain yang berlaku dalam masyarakat yang bersangkutan.

Salah satu penanggungjawaban pidana baik anak nakal adalah umur. Dalam hal itu, masalah umur merupakan masalah yang urgen bagi terdakwa untuk dapat diajukan dalam sidang anak. Umur dapat berupa umur minimum umur maksimum. Masalah umur tentunya harus dikaitkan dengan saat melakukan tidak pidana. Sehubungan masal umur, Pasal 4 Undang-Undang Nomor 3 Tahun 1997 metapkan sebagai berikut.

I) Batasan umur anak nakal yang dapat diajukan ke sidang anak adalah sekurang-kurangnya 8 (delapan) tahun tetapi belum mencapai umur (delapan belas) tahun dan belum pernah kawin.

2) Dalam hal anak melakukan tidak pidana pada batas umur sebagaimana dimaksud dalam ayat (I) dan diajukan kesidang pengadilan setelah anak yang bersangkutan melampaui batas umur tersebut, tetapi belum mencapi umur 21 (dua puluh satu) tahun, tetap diajukan kesidang anak. Jelaslah rumusan di atas, bahwa batas umur anak nakal minimum adalah 8 (delapan) tahun dan maksimum 18 (delapan belas tahun) atau belum pernah kawin. Sedang maksimum untuk dapat diajukan ke sidang anak adalah umur 21 tahun, asalkan saat melakukan tidak pidana belum mencapai umur 18 (delapan belas) tahun dan belum pernah kawin. Perbedaan umur dalam undang-undang ini pun mengatur mengenai kualifikasi umur dikaitkan dengan bentuk sanksi pidana yang dapat dijatuhkan hakim. Bagi anak yang masih berumur 8 (delapan) hungga 12 (dua belas) tahun hanya dikenakan tidakan, sedang terhadap anak yang berusia di atas I 2 (dua belas) hingga 18 (delapan belas) tahun tidak hanya tindakan yang dapat dijatukan, tetapi dapat pula dijatukan pidana. Pembedaan perlakuan tersebut didasarkan atas pertumbuhan perkembangan fisik, mental, dan sosial anak.

Menurut peneliti hukum pidana dalam kaitannya pada hukum wasiat adalah jika penerima wasiat berniat jahat/bertindak pidana seperti melakukan pembunuhan untuk mempercepat mendapatkan wasiat tersebut maka wasiatnya batal demi hukum.

\section{KESIMPULAN}

Untuk mentukan batasan kedewasaan dan kecakapan hukum pewasiat dalam hal ini sebagai kepastian hukum yang di atur dalam Kompilasi Hukum Islam dan Kitab UndangUndang Hukum Perdata. Kompilasi Hukum Islam (KHI) Pasal 194 ayat I menjelaskan bahwa orang yang telah berumur sekurang-kurangnya 21 (dua puluh satu) tahun, berakal sehat dan tanpa adanya paksaan dapat mewasiatkan sebagian harta bendanya pada orang lain ini mengacu pada pasal $330 \mathrm{KUH}$ perdata. Sedangkan dalam Kitab UndangUndang Hukum Perdata menyebutkan dalam Pasal 897 menjelaskan anak-anak di bawah umur yang belum mencapai umur 18 (delapan belas) tahun penuh tidak diperkenankan membuat surat wasiat. Bisa dilihat bahwa apabila pewasiat yang dilakukan tanpa memenuhi syarat dari batasan umur tersebut maka pewasiat tidak diperkenankan untuk membuat surat wasiat ini mengacu pada pasal 426 KUH Perdata. Karena dari sisi hukum pada usia minimum orang yang mewasiatkan hartanya dapat mempertangungjawabkan apa yang sudah melakukan. Hal itu dikarenakan untuk menentukan adanya kepastian hukum secara sosiologis diketahui pewasiat dapat bertenggung jawab. Kompilasi Hukum Islam dalam menentukan batasan kedewasaan dan kecakapan dalam membuat wasiat menganut para pakar psikologi seperti menurut Elizabeth $B$. Hurlock yang dikutip oleh Yudik Jahja dewasa awal dimulai dari umur 2I-40 tahun. Sedangkan Kitab Undang-Undang Hukum Perdata menganut para pakar Psikologi seperti menurut Freud (Bischof: 1976) dikutip oleh Hendra Ahdhiat dewasa awal dimulai dari umur |8-2| tahun. Persamaan konsepsi kedewasaan dan kecakapan hukum pewasiat menurut Kompilasi Hukum Islam dan Kitab Undang-undang Hukum Perdata menjelaskan syarat-syarat pewasiat yaitu berakal sehat, warga Indonesia, harta milik sendiri, harta wasiat dapat berlaku setelah pewasiat meninggal dunia, apabila wasiat itu dialukan secara lisan maupun tertulis 
hendaknya pelaksanaannya dilakukan di hadapan 2 (dua) orang saksi atau dihadapan notaris dan pewasiat dapat mencabut wasiatnya. Ada perbedaan antara Kompilasi Hukum Islam dan Kitab Undang-Undang Hukum Perdata adalah dalam penentuan kedewasaan dan kecakapan hukum pewasiat menurut Kompilasi Hukum Islam menjelaskan bahwa orang yang berwasiat harus berumur 2I (dua pulu satu) tahun. Sedangkan menurut Kitab Undang-undang Hukum Perdata menjelaskan bahwa orang yang berwasiat harus berumur 18 (delapan belas) tahun. Dari perbedaan ini menunjukan ambiguitas (ketidaktentuan; ketidakjelasan) dari kedua hukum tersebut dari tata urut perundangundangan maka Kitab Undang-Undang Hukum Perdata lebih tinggi tingkatanya. Kompilasi Hukum Islam ialah intruksi dari persiden dan secara tingkatanya di bawah Undang-Undang.

\section{DAFTAR PUSTAKA}

Abdul Baqi, Muhammad Faud,Al-lu'lu'u Wa Al-Marjanu Fima Ittafaqa'alayha Asy-Syaykhani al-Bukhariyyu Wa Muslimun, Di terjemahkan oleh Muhammad Suhadi, Anas Habibi, Tony Timur dengan judul, Al-Lu'Lu' Wal Marjan Mutiara Hadits Sahih Buhari dan Muslim Jakarta Timur, Umul Qura, Cet 6, 2014.

Afandi, Ali, Hukum Waris, Hukum Keluarga Dan Hukum Pembuktian. Jakarta, Rineka Cipta, Cet, 4, 1997.

Ahdhiat, Hendra, Pisikologi Hukum, Bandung, CV Pustaka Setia, Cet. I, 20II.

Al Asqalani, Ibnu Hajar, Fathul Baari Syarh Shahih Al Bukhari, Di terjemahkan oleh Amirudin dengan judul, Fathul Baari Penjelasan Kitab Shahih Al Bukhari, Jakarta Selatan, Pustaka Azzam, jilid I5, , 2007.

Amirin. M, Menyusun Rencana Penelitian. Jakarta, CV Rajawali, Cet. 2, 1990.

Andiko, Toha, Ilmu Qawa'id Fiqhiyyah, Panduan Praktis dalam Merespon Problematika Hukum Islam Kontemporer, Yogyakarta, Teras, Cet. I, $201 \mathrm{I}$.

Anshori, Abdul Ghofur, Harahab Yulkarnain, Hukum Islam Dan Perkembangannya Di Indonesia. Yogyakarta, Kreasi Total Media, 2008.

Anwar, Samsul, Hukum Perjanjian Syariah Studi Tentang Teori Akad dalam Fikih Muamalat,jakarta, PT. Raja Grafindo Perseda, Ce.2, 2010.

Bungin, M. Burhan, Penelitian Kualitatif, Komunikasi, Ekonomi, Kebijakan Publik, Dan Ilmu Sosial Lainnya, Jakarta, Kencana Prenada Media Group, Cet.3, 2009.
Danim, Sudarwan, Menjadi Peneliti Kualitatif. Bandung, Pustaka Setia, 2000.

Demita, Pisikologi Perkembangan, Bandung, PT Remaja Prosdakarya, Cet. 7, 2012.

Departemen Agama RI, Al Qur'an dan Terjemahnya, Jakarta Timur, PT Insan Media Pustaka, 2013.

Djazuli. A, Ilmu Fikih, Pengalian, Pengembangan, dan Penerapan Hukum Islam, Jakarta, Kencana, Cet.6, 2006.

Ghony M, Djunaidi, dan Almanshur Fauzan, Metode Penelitian Kualitatif, Jogjakarta, Ar-Ruzz Media, Cet. I, 2012.

Gunarsa, Singgih D., Dari Anak Sampai Usia Lanjut, Bunga Rampai Pisikologi Perkembangan, Jakarta, PT BPK Gunung Mulia, 2009.

Hadi, Sutrisno, Metodologi research. Yogyakarta, Yayasan Penerbit Fakultas Psikologi UGM, Cet XII, 1982.

Halim, Ridwan, Hukum Perdata dalam Tanya Jawab, Jakarta, Ghalia Indonesia, Cet.4, 1990.

Hasbi Ash-Shiddieqy, Teungku Muhammad, Filsafah Hukum Islam, Semarang, PT. Pustaka Rizki Putra, Cet.I, 2013.

Hernoko, Agus Yudha, Hukum Perjanjian Asas Proposionalitas Dalam Kontrak Komersial, Jakarta, Kencana Prenada Media Group, Cet.3, 2013.

Ibrahim Johnny,Teori dan Metodologi Penelitian Hukum Normatif, Malang, Bayumedia Publishing, 2006.

Imam Malik, Muwathha' Al Imam Malik, Di terjemahkan oleh, Adib Basri Muthofa dkk, Terjemah Muwathha' Al Imam Malik, Semarang, CV. Asy Syifa', Cet. I, 1992.

Jahja, Yudik, Psikologi Perkembangan, Jakarta, Kencana Prenadamedia Group, Cet.3, 2013.

Kartono, Kartini, Psikologi Anak, Bandung, CV. Mandar Maju, Cet.6, 2007.

Koto, Alaiddin, Ilmu Figh dan Usul Figh Sebuah Pengatar Edisi Revisi, Jakarta, PT. Grafindo Perseda, Cet.4, 201 I.

Mubarak, Jaih, Kaidah Fiqih, (Sejarah dan Kaidah Asasi), (Jakarta, Raja Grafindo Perseda, 2002.

Muhammad, Abdulkadir, Hukum Perdata Indonesia, PT Citra Aditiya Bakti, Cet.5, 2014.

Muhammad, Ismail Syah, dkk, Filsafat Hukum Islam, Jakarta, Bumi Aksara, Cet.3, 1999. 
Muljadi, Kartini, Widjaja Gunawan, Prikatan yang Laihir dari Perjanjian, Jakarta, PT Raja Grafindo Perseda, 2008.

Mulyadi, Lilik, Wajah Sistem Peradilan Pidana Anak Indonesia, Bandung, P.T.Alumni, Cet.I, 2014.

Muwafaqudin Abu Muhammad Abdullah bin Ahmad bin Qudamah Al-Maqdisi, Umdatul Fiqh Fil Madzhabil Hanbali,Diterjemahkan oleh Muhammad Al-Fatih dan Hawin Murtadlo, dengan judul, Umdatul Figh Fiqih Dasar Untuk Para Pemula, Solo, Al Qowam, Cet. I, 2014.

Patrik, Purwahid, Dasar-Dasar Hukum Perikatan (Perikatan Yang Lahir Dari Perjanjian Dan Dari Undang-Undang), Bandung, Mandar Maju, Cet. I, 1994.

Perangin, Effendi, Hukum Waris. Jakarta, PT Raja Grafindo Perseda, 1997.

Rofiq, Ahmad, Hukum Perdata Islam Di Indonesia Edisi Revisi, Jakarta, PT Raja Grafindo Persada, 2015.

Saebani, Ahmad Beni, Falah Syamsul, Hukum Perdata Islam Di Indonesia, Bandung, CV. Pustaka Setia, Cet.I, 2011.

Sayyid, Sabiq, Figh Sunnah,Di terjemahkan oleh Mujahid Muhayan dengan judul, Figh Sunnah, Jakarta, Pena Budi Aksara, Cet.5, jilid 5, 2013.

Suharsimi, Prosedur Penelitian. Yogyakarta, Rineka Cipta, Cet II.

Sunggono, Bambang, Metodologi Penelitian Hukum, Suatu Pengantar. Jakarta, PT. Raja Grafindo Persada, 1998.

Tamakiran, Asas Asas Hukum Waris Menurut Tiga Sistem Hukum. Bandung, CV. Pionir Jaya, 1992.

Wahid, Abdul dan Muhibbin Muh, Hukum Kewarisan Islam Sebagai Pembaruan Hukum Positif Di Indonesia. akarta, Sinar Grafika, 2009.

Waluyo, Bambang, Pidana dan Pemidanaan, Jakarta, Sinar Grafika, Cet.3, 2008.

Wetboek, Bugerlijk, Kitab Undang-Undang Hukum Perdata. Bandung, Citra Umbara, Cet. 6, 2013.

Zuhaili, Wahbah, Al-Fiqhu Asy-Syafi'i Al-Muyassar, Diterjemahkan oleh Muhammad Afifi, Abdul Hafiz dengan judul, Fiqih Imam Syafi'i, Jakarta, Almahira, Cet. I, 2010.

Zulfa, Eva Achjani, Gugurnya Hak Menuntut Dasar Penghapus, Peringan, dan Pemberat Pidana, Bogor, Ghalia Indonesia, Cet.2, 2013.

Zulfa, Eva Achjani, Fiqih Islam Wa Adillatuhu, Di terjemahkan oleh Abdul Hayyie al-Kattani, dkk dengan judul, Fiqih
Islam Wa Adillatuhu Hak Anak, Wasiat, Wakaf, Warisan, Jakarta, Gema Insani, Jilid I0, 201 I.

Zulfa, Eva Achjani, Kitab Undang-Undang Hukum Perdata (Burgerlijik Wetboek) oleh Subekti dan Tjitrosudibio, dengan judul Kitab Undang-Undang Hukum Perdata dan Undang-Undang Pokok Agraria dan Udang-Undang Perkawinan, Jakarta, PT Pradnya Paramita, Cet.13, 2005. 